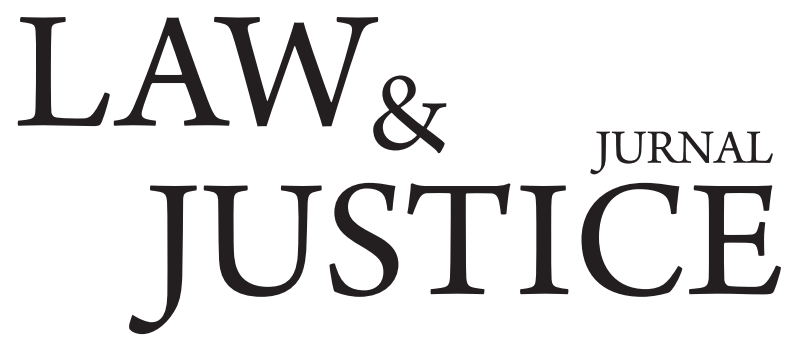

Volume 4, Nomor 1, April 2019

\title{
Politik Hukum Badan Usaha Milik Daerah (BUMD) dalam Kegiatanbisnis untuk Mewujudkan Kesejahteraan Sosial
}

\author{
Sri Widiyastuti \\ Fakultas Hukum, Universitas Tanjungpura, Pontianak, Kalimantan Barat \\ email: sri.fh.untan12@gmail.com
}

\begin{abstract}
Konsep negara dan bisnis memiliki perbedaan yang cukup mendasar, sehingga dalam tataran praktisnya seringkali ada masalah yakni benturan kepentingan keduanya khususnya dalam kegiatan Badan Usaha Milik Daerah (BUMD) yang bidang produksinya berkaitan dengan hajat hidup orang banyak, dimana dampaknya tujuan untuk mencapai kemakmuran masyarakat belum tercapai secara optimal. Tujuan dari kajian ini adalah untuk memahami dua unsur penting yakni unsur bisnis dan unsur negara yang harus sinergi dalam pengelolaan BUMD terkait upayanya untuk mencapai tujuan negara yakni kemakmuran masyarakat. Metode penelitian yang digunakan adalah penelitian doktrinal yang mengkaji data sekunder berupa bahan pustaka meliputi bahan hukum primer, sekunder, dan tersier. Pendekatan yang digunakan adalah pendekatan perundangundangan, sejarah, dan konseptual, serta cara analisis kualitatif dengan interpretasi gramatikal, sistematis, dan teologis. Hasil penelitian memperlihatkan bahwa konsep bisnis harus ada dalam fungsi pemerintahan daerah sebagai implementasi kegiatan pemerintahan dalam kerangka otonomi daerah, sehingga makna bisnis yang dijalankan oleh pemerintah daerah esensinya adalah mempercepat terwujudnya kesejahteraan masyarakat. Sedangkan, antinomi dalam pengelolaan BUMD, yakni benturan antara unsur negara yang identik dengan pelayanan publik dengan unsur bisnis yang karakteristiknya mengejar keuntungan harus disikapi dengan perubahan paradigma pemerintah daerah dalam memaknai keuntungan BUMD. Oleh karena itu, disarankan untuk memberikan rumusan yang jelas mengenai tugas pelayanan umum dalam bidang-bidang produksi yang terkait hajat hidup orang banyak dalam regulasi yang mengatur mengenai BUMD.
\end{abstract}

Keywords: Politik Hukum, Bisnis, Badan Usaha Milik Daerah (BUMD), Kesejahteraan Sosial.

\section{Pendahuluan}

Badan Usaha Milik Daerah (BUMD) adalah badan usaha yang modalnya (baik sebagian atau seluruhnya) dimiliki oleh daerah, ${ }^{1}$ dan merupakan motor penggerak perekonomian di daerah sebab ia didirikan dengan visi untuk memberikan

\footnotetext{
1 Republik Indonesia, Peraturan Pemerintah Nomor 54 Tahun 2017 Tentang Badan Usaha Milik Daerah, Pasal 1 butir (1).
}

manfaat bagi perkembangan perekonomian daerah, menyelenggarakan pelayanan umum, dan memperoleh keuntungan. ${ }^{2}$ Keberadaan BUMD ini sangat strategis, mengingat jumlah perusahaan yang dimiliki oleh pemerintah daerah ini cukup besar (signifikan), bahkan jauh lebih besar jika dibandingkan dengan jumlah perusahaan yang

\footnotetext{
2 Republik Indonesia, Undang-Undang Nomor 23 Tahun 2014 Tentang Pemerintahan Daerah, Pasal Ayat (4).
} 
dimiliki oleh pemerintah pusat (BUMN). Data Badan Pusat Statistik (BPS) pada Tahun 2014 saja menyebutkan bahwa jumlah BUMN aktif berjumlah 119 yang terdiri dari 14 Perum, 85 Persero dan 20 PT. (Persero) Tbk, ${ }^{3}$ dengan total aset tahun 2014 mencapai 4.577,97 triliun rupiah. ${ }^{4}$ Sedangkan, jumlah BUMD pada tahun 2014 tercatat sebanyak 777 perusahaan, yang terdiri dari 115 perusahaan milik Pemerintah Provinsi, 662 perusahaan milik Pemerintah Kabupaten/ Kota, ${ }^{5}$ dan total aset sebesar 662,1 triliun rupiah. ${ }^{6}$ Data ini menunjukan bahwa BUMD merupakan perusahaan yang sangat potensial sebagai motor penggerak perekonomian di daerah sebagaimana diuraikan di awal, yang nantinya juga menopang perekonomian nasional.

Namun, hasil penelitian dari Lembaga Ilmu Pengetahuan Indonesia (LIPI) menyebutkan bahwa kontribusi BUMD pada pendapatan atau kas daerah masih sangat kecil, dan lebih banyak membebani anggaran negara. Salah satu masalah dalam pengelolaan BUMD sebagai sebuah entitas bisnis adalah adanya benturan visi yang ingin dicapai dengan misi yang dilakukannya. ${ }^{7}$ Sebuah penelitian menyebutkan bahwa faktor internal organisasi berupa tuntutan fungsi sosial BUMD menyebabkan BUMD tidak fokus terhadap visi utamanya, ${ }^{8}$ yaitu mengembangkan perekonomian daerah untuk mendukung kepentingan nasional melalui peningkatan Pendapatan Asli Daerah (PAD). Tugas pemerintah daerah (negara) sebagai pelaku usaha (entrepreuner) ini sangat menarik dikaji sebab konsep antara negara dan bisnis memiliki perbedaan yang mandasar yang saling bertentangan, dimana pelaksanaannya kedua unsur ini terbukti menghambat tujuan (visi) mengembangkan perekonomian daerah yang berarti menghambat tujuan bagi sebesar-besar kemakmuran rakyat. Unsur negara yang fokus pada pelayanan publik dengan unsur keuntungan yang menjadi fokus tujuan bisnis saling berbenturan

3 Badan Pusat Statistik, 2014. Statistik Keuangan BUMN dan BUMD 2014, Subdirektorat Statistik Keuangan, Badan Pusat Statstk, Jakarta, Indonesia, Hal 28.

$4 \quad$ Ibid, Hal 29.

$5 \quad$ Ibid, Hal 35.

$6 \quad$ Ibid, Hal 37.

7 Jiwa Sarana, Pusat Penelitian Ekonomi, Lembaga Ilmu Pengetahuan Indonesia (P2E-LIPI), 2010. Revitalisasi BUMD Dalam Perekonomian Daerah. LIPI Press, Hal iii.

8 Wihana Kirana Jaya. 2007. Policy Brief Badan Usaha Milik Daerah (BUMD). Dalam Studi Potensi Pendapatan Asli Daerah Provinsi Daerah Istimewa Yogyakarta, Pusat Studi Ekonomi dan Kebijakan Publik (PSE-KP) UGM, Hal 13. dan tidak mudah menyinergikan dalam sebuah regulasi pengelolaan perusahaan negara tersebut. Benturan antara dua nilai ini (bisnis dan pelayanan umum), dalam teori hukum dikenal dengan konsep antinomi, ${ }^{9}$ dimana keduanya tidak bisa dipisahkan dalam sebuah sistem hukum.

Undang-Undang Nomor 23 tahun 2014 Tentang Pemerintahan Daerah (UU Pemda) maupun Peraturan Pemerintah Nomor 54 Tahun 2017 Tentang BUMD (PP BUMD) mengatur bahwa bentuk hukum dari perusahaan BUMD adalah Perusahaan Umum Daerah (Perumda) dan Perusahaan Perseroan Daerah (Perseroda). ${ }^{10}$ Dalam regulasi tersebut dijelaskan bahwa Perumda fokus pada aspek pelayanan umum sedangkan Perseroda fokus pada profit. Jadi, sebenarnya telah ada sebuah road map mengenai pengelolaan BUMD terkait posisi pemerintah daerah sebagai pelaku usaha. Namun, pengelolaan kebutuhan strategis yang terkait hajat hidup orang banyak memerlukan investasi yang besar, yang tidak bisa ditanggung sendiri oleh kemampuan pemerintah daerah. Dalam perkembangannya, era globalisai ekonomi dan otonomi daerah berdampak pada perlunya upaya pemberdayaan melalui peluang besar investasi, sehingga ada bidang strategis yang tak luput dari kebijakan ini, misalnya, bidang air.

Jika mencermati kebijakan swastanisasi air minum yang dijalankan oleh Pemerintah Provinsi (Pemprov) DKI Jakarta bersama dengan operator PT. PAM Lyonnaise Jaya (Palyja) dan PT. Aetra Air Jakarta (Aetra), maka nampak jelas rumitnya benturan kepentingan antara bisnis dan pelayanan umum dalam pengelolaan air. Kebijakan swastaninasi air ini bermula dari adanya kerjasama antara PAM Jaya sebagai BUMD pengelola air di DKI Jakarta berdasarkan Peraturan Daerah DKI Jakarta Nomor 3 Tahun 1977 dan SK Mendagri Nomor Pem/10/53/13350 dan diundangkan dalam lembaran Daerah Khusus Ibukota Jakarta Nomor 74 Tahun 1977 11 dengan PT. Palyja dan PT.Aetra. Terlepas dari adanya kesalahan prosedur dalam pembuatan perjanjian kerjasamanya itu, perkembangan kegiatan perusahaannya menyebabkan kedudukan Pemerintah DKI tidak

\footnotetext{
9 Sudikno Mertokusumo, 2002. Teori Hukum. Bahan Kuliah Magister Ilmu Hukum UGM, Hal 25.

10 PP BUMD, Pasal 4 dan UU Pemda, Pasal 334 dan 339.

11 Putusan Mahkamah Agung Nomor 31/K/PDT/2017 Tentang gugatan masyarakat terhadap kebijakan privatisasi air Pemerintah Provinsi DKI Jakarta, pertimbangan hukum (dalildalil) hakim butir (35), Hal 18.
} 
lagi dominan sebab prosentase kepemilikan saham dalam BUMD 95\% dikuasai oleh swasta, ${ }^{12}$ sehingga proses pengusahaan, dan distribusi air di bawah kendali pihak swasta.

Sejak swasta mulai mengelola air Jakarta dari tahun 1998 hingga tahun 2011 hanya $62 \%$ wilayah Jakarta yang mendapatkan layanan air. ${ }^{13}$ Dampaknya, Sistem Pembayaran Imbalan Air (water charge) untuk menutupi seluruh kebutuhan pembiayaan menyebabkan masyarakat miskin tidak mampu membeli harga air yang disediakan oleh PAM Jaya. ${ }^{14}$ Fakta ini memperlihatkan bahwa Pemprov DKI Jakarta justru gagal memenuhi hak masyarakat atas air khususnya mereka yang berasal dari ekonomi tidak mampu. Artinya, kondisi ini memperlihatkan adanya kecenderungan unsur profit yang lebih dominan menjadi pertimbangan pengambilan kebijakan pengelolaan perusahaan pemerintah tersebut. Hal ini sekaligus membuktikan bahwa tidaklah mudah mencari solusi atas benturan nilai bisnis dengan nilai pelayanan umum ketika sektor produksi sudah melibatkan pihak swasta. Oleh karena itu, kajian mengenai konsep antinomi dalam pengelolaan BUMD penyedia kebutuhan strategis (terkait hajat hidup orang banyak) sangat penting dilakukan. Tujuan dari kajian ini adalah untuk memahami dua unsur penting yakni unsur bisnis dan unsur negara yang harus sinergi dalam pengelolaan BUMD terkait upayanya untuk mencapai tujuan negara yakni kemakmuran masyarakat. Oleh karena itu, sangat penting mencari jawaban atas makna bisnis dalam fungsi pemerintahan di daerah, dan perlunya sinergi antara unsur bisnis dan unsur pemerintahan dalam fungsi pemerintah daerah sebagai pelaku usaha.

\section{Kajian Literatur}

Politik Hukum Sistem Perekonomian Indonesia Undang-Undang Dasar Negara Republik Indonesia Tahun 1945 (UUD 1945) merupakan hukum dasar di negara Indonesia yang ditetapkan oleh para pendiri negara dalam hal ini Badan Penyelidik Usaha-Usaha Persiapan Kemerdekaan Indonesia (BPUPKI) pada tanggal 18 Agustus 1945. Undang-undang dasar merupakan sebagian dari hukum dasarnya suatu negara dan bersifat

12 Ibid, Pertimbangan Hukum Hakim butir (58), Hal 22.

13 Ibid, Pertimbangan Hukum Hakim butir (59), Hal 22.

14 Ibid, Pertimbangan Hukum Hakim butir B2, Hal 29. tertulis, ia berdampingan dengan aturan-aturan dasar yang tidak tertulis, yang terpelihara dalam praktik penyelenggaraan negara. ${ }^{15}$ UUD 1945 telah mengalami proses revisi (amandemen) sebanyak empat kali. Salah satu pasal yang mengalami revisi adalah Pasal 33 yang mengatur mengenai perekonomian nasional dan kesejahteraan sosial, yang menjadi landasan politik hukum sistem perekonomian Indonesia. Ia sarat dengan nilai-nilai filsafat Pancasila sebagai pandangan hidup bangsa Indonesia yang secara formal tertuang dalam Pembukaan UUD 1945. Para tokoh seperti Emil Salim, Mubyarto, dan Sumitro Djojohadikusumo menjabarkan ideologi Pancasila melalui rincian sila-sila Pancasila dalam dunia ekonomi dan bisnis, dimana rumusan kalimatnya mengandung nilainilai yang cukup universal (ketuhanan, moral, dan kemanusiaan), sehingga ketentuan Pasal 33 UUD 1945 ini sangat pantas dijadikan landasan sistem ekonomi Indonesia, dan dipandang sebagai dasar ekonomi kerakyatan. ${ }^{16}$

Pasal 33 UUD 1945 ayat (1) meyebutkan bahwa "Perekonomian disusun sebagai usaha bersama berdasar atas asas kekeluargaan." Pasal ini memiliki makna bahwa kebangkitan ekonomi Indonesia tidak terletak pada aktivitas atau gerakan perorangan namun ia ada pada sebuah usaha bersama, dimana muaranya adalah pada kemakmuran bersama, bukan kemakmuran orang per orang. Ayat (2) menyebutkan bahwa "Cabangcabang produksi yang penting bagi negara dan yang menguasai hajat hidup orang banyak dikuasai oleh negara." Selanjutnya ayat (3) menjelaskan bahwa "Bumi, air, dan kekayaan yang terkandung di dalamnya dikuasai oleh negara dan dipergunakan untuk sebesar-besar kemakmuran rakyat.” Ayat (2) dan (3) ini menjelaskan perbedaan sistem ekonomi Indonesia dengan sistem ekonomi yang dianut negara-negara lain, yakni sektor produksi bidang strategis dan berkenaan dengan hajat hidup orang banyak diletakan pada penguasaan negara, bukan orang per orang atau swasta.

Pada amandemen keempat, ada penambahan dua ayat yakni ayat (4) dan ayat (5). Pada Ayat (4) disebutkan bahwa, "Perekonomian nasional diselenggarakan berdasar atas demokrasi ekonomi

\footnotetext{
15 Sekretariat Majelis Permusyawaratan Rakyat, 2011. UndangUndang Dasar 1945, Cetakan kesepuluh, Sekretariat Jenderal MPR RI, Penjelasan UUD 1945 bagian Umum.

16 Adi Sulistiyono dan Muhammad Rustamji, 2009. Hukum Ekonomi Sebagai Panglima. Sidoarjo: Masmedia Buana Pustaka. Hal 36-38.
} 
dengan prinsip kebersamaan, efesiensi berkeadilan, berkelanjutan, berwawasan lingkungan, serta dengan menjaga keseimbangan kemajuan dan kesatuan ekonomi nasional." Dijelaskan bahwa demokrasi ekonomi merupakan tata kelola perekonomian yang dilakukan oleh semua elemen masyarakat dengan prinsip-prinsip keadilan, kebersamaan dan seterusnya. Tujuan yang hendak dicapai adalah kemakmuran bersama-sama. ${ }^{17}$ Jika mencermati rekdasi kalimatnya, ayat (4) ini secara politik hukum berupaya mengakomodir arus globalisasi hukum dan ekonomi. Kesimpulan ini didapat dari kalimat efesiensi, kemajuan, kemandirian. Dalam Pasal 33 ayat (4) ini ditegaskan bahwa sekalipun sektor produksi dikerjakan secara bersama-sama dengan tujuan mencapai kemakmuran bersama, namun sektor swasta tidak diperkenankan mengelola kegiatan strategis yang berkaitan dengan hajat hidup orang banyak. Dengan kata lain, bidang yang berkaitan dengan hajat hidup orang banyak mutlak harus dikuasai oleh negara. Mencermati pasal-pasal ini, maka jelas tergambar politik hukum sistem perekonomian Indonesia dalam kerangka besar negara kesejahteraan.

\section{Kesejahteraan Sosial}

UUD 1945 merupakan sebagian dari hukum dasar, dimana untuk dapat memahami makna yang terkandung dalam hukum dasar tidak cukup dengan membaca rumusan teks pasal-pasalnya (batang tubuh), namun harus memahami latar belakang (suasana kebatinan) dari Undang-Undang Dasar tersebut. ${ }^{18}$ Proklamasi merupakan komitmen bangsa Indonesia mengenai kemerdekaan yang didalamnya mengandung prinsip-prinsip dasar perikehidupan bernegara, ia kemudian dijabarkan ke dalam Pembukaan UUD 1945, sehingga pokokpokok pikirannya melandasi lahirnya hukum di Indonesia baik tertulis maupun tidak tertulis, termasuk isi batang tubuh UUD 1945. Dengan demikian, Pembukaan UUD 1945 merupakan pokok kaidah negara yang fundamental dan memiliki hakikat kedudukan hukum yang tetap. Maknanya, secara hukum Pembukaan UUD 1945 tidak dapat diubah sebab mengubah Pembukaan UUD 1945 sama halnya dengan merubah NKRI. ${ }^{19}$

17 Republik Indonesia, Undang-Undang Dasar Negara Tahun 1945, Bagian Penjelasan Pasal 33.

18 Ibid, Penjelasan, Bagian I Umum.

19 https://sistempemerintahannegaraindonesia.blogspot. com/2016/04/isi-kedudukan-dan-makna-pembukaan-uud.
Pokok-pokok pikiran dalam Pembukaan UUD 1945 merupakan refleksi dari kondisi eksisting saat perumusan UUD 1945 dan suasana kebatinan pada saat pembentukan Negara Kesatuan Republik Indonesia (NKRI), sehingga dengan memahami isi dari pokok-pokok pikiran Pembukaan UUD 1945 akan memperjelas makna dan tujuan berdirinya NKRI. Secara garis besar Pembukaan UUD 1945 memuat empat hal pokok yang menjadi pijakan kehidupan bernegara. Empat hal pokok itu, (i) mengenai konsep negara kesatuan, (ii) tujuan negara untuk mewujudkan kesejahteraan sosial bagi seluruh rakyat, (iii) konsep kedaulatan rakyat, dan (iv) negara berdasar atas Ketuhanan Yang Maha Esa menurut dasar kemanusiaan yang adil dan beradab, sehingga ada kewajiban untuk memelihara budi pekerti dan cita-cita moral yang luhur. ${ }^{20}$

Pokok-pokok pikiran dalam Pembukaan UUD 1945 dijabarkan dalam pasal-pasal (batang tubuh) Undang-Undang Dasar 1945, sehingga Pembukaan UUD 1945 mempunyai hubungan langsung yang bersifat kausal organis dengan batang tubuh UUD 1945. Secara sistematis hubungan langsung ini dapat dilihat dari keterkaitan pokok pikiran mengenai Ketuhanan yang mengilhami pasal 29 UUD 1945, pasal 28 (UUD 1945 amandemen), lalu prinsip kemanusiaan, yang dijabarkan di pasal-pasal yang memuat mengenai hak asasi manusia. Kemudian, prinsip persatuan yang dijabarkan di pasal 18, pasal 35, pasal 36 UUD 1945. Sedangkan, pokok pikiran musyawarah dan mufakat dijabarkan pada pasal 2 s.d 24 UUD 1945. Pokok pikiran yang berkaitan dengan Keadilan sosial atau Sila kelima dijabarkan pada pasal 33 dan 34 UUD1945. Hal ini memperjelas bahwa Pembukaan UUD 1945 adalah kaidah pokok yang melandasi lahirnya produk hukum di Indonesia.

Jika melihat dari materi yang dimuat dalam batang tubuh UUD 1945, maka Indonesia termasuk ke dalam konstitusi ekonomi (economic constitution) bahkan konstitusi sosial (sosial constitution). ${ }^{21}$ Corak konstitusi ini sangat jelas terlihat pada muatan Pasal 33 UUD 1945. Pasal 33 intinya menyatakan bahwa Indonesia menganut sistem demokrasi ekonomi yakni kegiatan ekonomi yang ditopang oleh semua unit ekonomi (swasta baik perorangan maupun html.

20 Loc., Cit

21 Jimmly Asshiddiqie, Hukum Tata Negara dan Pilar-Pilar Demokrasi, Konstitusi Press, Jakarta, 2005, hlm 135. 
Badan Usaha, dan Pemerintah) untuk tujuan yang satu yakni kemakmuran bersama-sama. Mengingat tujuan tersebut, maka sektor produksi yang penting, strategis, dan berkaitan dengan hajat hidup orang banyak harus dikuasai oleh negara, tidak diperbolehkan dikuasai swasta baik perorangan maupun badan usaha. Hal ini merupakan bentuk kongkrit Indonesia sebagai negara hukum (rechstraat), dimana supremasi hukum menghendaki setiap aspek hidup diatur oleh undang-undang. ${ }^{22}$ Sebagai hukum dasar negara Indonesia, UUD 1945 mengatur mengenai keterlibatan negara dalam proses produksi, utamanya yang terkait dengan bidang strategis dan penguasaan sektor hajat hidup orang banyak.

Melihat sejarah proklamasi yang kemudian dijabarkan ke dalam Pembukaan UUD 1945 berikut batang tubuh UUD 1945, maka tatanan hukum Indoneisa ini sejalan dengan konsep Von Savigny yang mengemukakan hukum tersebut tidak dibuat, melainkan tumbuh dan berkembang dalam jiwa bangsa (volkgeist). Maknanya, hukum adalah tidak statis atau bahkan ketinggalan jaman. Ia sangat dinamis mengikuti spirit dan jiwa bangsa tersebut. $^{23}$ Konsep hukum sebagai bangunan budaya ini jika dikaitkan dengan konsep hukum responsif, maka nilai yang melandasi konsep kesatuan perekonomian nasional adalah nilai keadilan sosial sebagaimana rumusan bab XIV UUD 1945 yang berjudul Perekonomian Nasional Dan kesejahteraan Sosial. Makna dari rumusan judul tersebut adalah penyelenggaraan perekonomian nasional harus menuju pada tatanan kesejahteraan rakyat.

\section{BUMD Dalam Kegiatan Bisnis}

Peran strategis negara dalam perekonomian ini merupakan kongkritisasi Indonesia sebagai negara hukum (rechstraat), dimana supremasi hukum menghendaki setiap aspek kehidupan diatur oleh undang-undang. ${ }^{24}$ UUD 1945 sebagai hukum dasar negara Indonesia, ia mengatur mengenai keterlibatan negara dalam proses produksi, utamanya yang terkait dengan bidang strategis dan penguasaan sektor hajat hidup orang banyak. Peran strategis ini bermakna negara berwenang

22 Republik Indonesia, Undang-Undang Dasar Tahun 1945, Op.,Cit.,Pasal 1,2.

23 Khasazah, Friedrich Karl Von Savigny. Padjadjaran Jurnal Ilmu Hukum, Volume 2, Nomor 1 Tahun 2015 (ISSN 24601543), (E-ISSN 2442-9325), Hal 197.

24 Republik Indonesia, Op.,Cit.,, Pasal 1,2. untuk secara langsung intervensi dalam kegiatan ekonomi dan bisnis, termasuk di bidang strategis yang terkait dengan hajat hidup orang banyak. Prakteknya, negara melakukan penyertaan modal secara langsung dengan mendirikan perusahaan berupa Badan Usaha Milik Negara (BUMN) dan Badan Usaha Milik Daerah (BUMD).

Dalam kontek kegiatan BUMD, UndangUndang Nomor 23 Tahun 2014 Tentang Pemerintahan Daerah (UU Pemda) merupakan landasan hukum bagi daerah dalam mengelola kegiatan pemerintahan di daerah, termasuk kegiatan perekonomiannya berdasarkan asas otonomi seluas-luasnya dalam kerangka Negara Kesatuan Republik Indonesia. ${ }^{25}$ Konsep otonomi seluas-luasnya ini merupakan keleluasaan dalam mejalankan kewenangan yang diberikan oleh Pemerintah Pusat kepada Pemerintah Provinsi, Kabupaten dan/atau Kota untuk mengurus sendiri rumah tangga pemerintahannya, meningkatkan daya saing terkait dengan arus globalisasi dan prinsip demokrasi, pemerataan, keadilan, kekhususan, serta potensi dan keanekaragaman daerah dalam sistem Negara Kesatuan Republik Indonesia. Prinsipnya adalah untuk mempercepat terwujudnya kesejahteraan masyarakat. ${ }^{26}$

Perkembangan pengaturan BUMD ini tidak terlepas dari Undang-Undang Nomor 5 tahun 1962 Tentang Perusahaan Daerah. Dalam perjalanannya, BUMD masuk ke dalam salah satu materi UU Pemda yakni dalam Bab XII mulai Pasal 331 Sampai Pasal 343. Yang terbaru adalah pembentukan Peraturan Pemerintah (PP) Nomor 54 Tahun 2017 Tentang BUMD (PP BUMD) yang mulai diberlakukan pada Desember 2017. Pengaturan BUMD dari waktu ke waktu memang belum memberikan kondisi ideal bagi pengelolaannya, sebab Undang-Undang khusus BUMD hingga kini belum terbentuk, ia hanya diatur secara parsial dalam materi pemerintahan daerah. Menurut Peraturan Pemerintah, BUMD adalah badan usaha yang seluruh atau sebagian modalnya dimiliki oleh daerah. ${ }^{27}$ Sama halnya dengan rumusan Undang-Undang Nomor 5 Tahun 1962 Tentang Perusahaan Daerah, dimana Perusahaan Daerah ialah semua perusahaan yang didirikan dengan modal yang berasal dari

25 Republik Indonesia, Undang-Undang Nomor 23 Tahun 2014 Tentang Pemerintahan Daerah, Pasal 1 Ayat (2).

26 Ibid, Bagian Penjelasan.

27 Republik Indonesia, Peraturan Pemerintah Nomor 54 Tahun 2017 Tentang BUMD, Pasal 1 Ayat (1). 
kekayaan daerah yang dipisahkan, kecuali diatur lain oleh Undang-Undang. ${ }^{28}$ Dari sisi kepemilikan modal, pemerintah berperan sebagai pelaku usaha. Jika dikaitkan dengan dengan prinsip desentralisasi, Pemerintahan sebagaimana ditetapkan dalam pasal 18 Undang-Undang Dasar menghendaki agar daerah otonom yang dibentuk itu dapat mengatur dan mengurus rumah-tangganya sendiri dengan sebaik-baiknya. Oleh karena itu, diperlukan adanya sumber-sumber keuangan yang dapat memberdayakan daerah otonom tersebut. ${ }^{29}$ Oleh karenanya, dijelaskan bahwa pendirian Perusahaan Daerah ini selain pemenuhan misi pelayanan umum (misi sosial), juga ditujukan untuk mempertinggi produktivitas untuk menambah pendapatan daerah. Arah kebijakan dalam regulasi BUMD ini menarik untuk dikaji lebih dalam, sebab terdapat pertentangan nilai antara nilai bisnis dan sosial dalam konsep pengelolaan BUMD. Dalam teori hukum, pertentangan nilai ini disebut sebagai konsep antinomi. Dalam teori hukum yang dimaksud antinomi adalah konflik dalam sistem hukum antara dua unsur, dimana dua unsur ini saling bertentangan, namun tidak bisa dipisahkan satu sama lainnya. ${ }^{30}$

Apabila mencermat kegiatan bisnis, ia merupakan suatu aktivitas yang dilakukan oleh orang dan/atau badan usaha secara terus-menerus dan untuk tujuan mencari keuntungan. Menurut Richard Burton Simatupang, bidang usaha bisnis setidaknya dapat dibedakan ke dalam tiga bidang, yaitu perdagangan (commerce), industri (production), dan jasa (service). ${ }^{31} \mathrm{Jadi}$, ruh dari kegiatan bisnis adalah upaya mengejar profit. Sedangkan, kegiatan pemerintahan apabila dirunut dari isi Pembukaan UUD 1945, setelah proses kemerdekaan (alinea ketiga) hal yang dilakukan oleh Pemerintah (alinea ke empat) adalah membentuk pemerintahan untuk mewujudkan cita-cita nasional. Pemerintah Negara Indonesia yaitu Pemerintah Nasional yang bertanggung jawab mengatur dan mengurus bangsa Indonesia. Lebih lanjut dinyatakan bahwa tugas Pemerintah Negara Indonesia adalah melindungi seluruh bangsa dan tumpah darah Indonesia, yang 28 Republik Indonesia, Undang-Undang Nomor 5 Tahun 1962 Tentang Perusahaan Daerah, Pasal 2.

29 Ibid, Bagian Penjelasan (Umum).

30 Fence M. Wantu, Antinomi Dalam Penegakan Hukum Oleh Hakim, Mimbar Hukum, Volume 19, Nomor 3, Oktober 2007, Hal 335-485.

31 Zaeni Asyhadie, 2005. Hukum Bisnis, Prinsip Dan Pelaksanaanya Di Indonesia, Jakarta, Rajawali Press, Hal 28. maknanya negara bertanggung jawab pada aspek kesejahteraan (sandang, papan, pendidikan, kesehatan dan kebutuhan dasar lainnya), serta aspek keadilan sosial. ${ }^{32}$ Dengan demikian, ruh negara (pemerintahan) adalah melakukan kebaikan bagi warganya.

Era otonomi daerah memberi peluang yang besar bagi investasi di daerah, tidak terkecuali bidang yang strategis. Mencermati bidang-bidang produksi strategis seperti air, listrik, minyak dimana sangat terkait dengan hajat hidup orang banyak, maka harus ada proses politik hukum yang baik yang sesuai dengan mandat konstitusi. Hal ini dimaksudkan agar kebijakan pemerintah daerah tidak condong ke unsur bisnisnya saja namum menempatkan cita-cita nasional dalam kerangka kebijakannya.

\section{Metode Penelitian}

Penelitian ini merupakan penelitian hukum normatif (doktrinal) melalui penelitian kepustakaan, yaitu penelitian yang dilakukan dengan cara mengumpulkan data dari berbagai pustaka yang berhubungan dengan masalah yang diteliti melalui pendekatan perundang-undangan (statue approach), ${ }^{33}$ yakni proses penelusuran produk perundangan-undangan baik dari sisi regulasi, maupun proses legislasinya. ${ }^{34}$ Selain itu, digunakan juga pendekatan konseptual yakni mempelajari berbagai doktrin atau pandanganpandangan hukum ${ }^{35}$ mengenai antinomi di dalam teori hukum. Data yang diperlukan adalah data sekunder, ${ }^{36}$ terdiri dari bahan hukum primer, yaitu bahan hukum yang bersifat mengikat, ${ }^{37}$ antara lain meliputi Undang-Undang Dasar Negara Republik Indonesia Tahun 1945, Undang-Undang Nomor 5 Tahun 1962 Tentang Perusahaan Daerah, UndangUndang Nomor 19 Tahun 2003 Tentang Badan Usaha Milik Negara (BUMN), dan peraturan perundangan lain yang terkait. Kemudian,

32 Republik Indonesia, , Op.Cit., Bagian Penjelasan (Umum).

33 Johny ibrahim, 2007, teori, metode dan penelitian hukum normatif, Bayumedia Publishing, Malang-Jawa Timur, Hal 30.

34 Peter Mahmud Marzuki, 2017. Penelitian Hukum, Edisi Revisi. Jakarta, Kencana, Hal 136-137.

35 Ibid, Hal 177-180.

36 Data sekunder adalah data yang diperoleh dari bahan pustaka, mencakup dokumen-dokumen resmi, buku-buku, hasilhasil penelitian yang berwujud laporan, buku harian. Lihat Soerjono Soekanto. 2007. Pengantar Penelitian Hukum. UI Press, Jakarta, Hal 12.

37 Burhan ashshofa. metode penelitian hukum. (Jakarta: Rineka Cipta, 2007), hal 103. 
bahan hukum sekunder yaitu bahan hukum yang memberikan penjelasan mengenai bahan hukum primer, ${ }^{38}$ yang terdiri dari berbagai referensi baik buku, hasil penelitian, jurnal ilmiah yang relevan dengan obyek penelitian ini. Sedangkan, bahan hukum tersier adalah bahan hukum yang memberikan kejelasan bahan hukum sekunder berupa Kamus Bahasa Indonesia dan Kamus Hukum (Black's Law Dictionary).

Pengumpulan data dilakukan dengan cara studi dokumen/kepustakaan yakni meneliti data yang diperoleh berupa bahan-bahan pustaka/ dokumen yang relevan dengan permasalahan yang diteliti. Setelah proses pengumpulan data, maka tahap selanjutnya adalah pengolahan data. Peter Mahmud dalam bukunya Penelitian hukum menyebutkan langkah-langkah penelitian. Langkah-langkah tersebut antara lain mengidentifikasi fakta hukum dan mengeliminir hal-hal yang tidak relevan untuk menetapkan isu hukum yang hendak dipecahkan, pengumpulan bahan-bahan hukum yang relevan, melakukan telaah atas isu hukum yang diajukan berdasarkan bahan-bahan yang telah dikumpulkan, menarik kesimpulan dalam bentuk argumentasi yang menjawab isu hukum, memberikan preskripsi berdasarkan argumentasi yang telah dibangun di dalam kesimpulan. ${ }^{39}$

Data dikelompokan dan diseleksi (dipilah sesuai relevansinya dengan obyek penelitian), kemudian dianalisis dengan metode kualitatif yaitu penjabaran dan pembahasan terhadap hasil penelitian yang didasarkan pada norma hukum, selanjutnya dilakukan interpretasi menggunakan metode interpretasi sistematis, gramatikal, dan teologis ${ }^{40}$ untuk menjawab permasalahan dalam penelitian.

\section{Hasil Dan Pembahasan}

\section{Makna Bisnis Dalam Fungsi Pemerintahan Di Daerah}

Salah satu tugas dan fungsi negara adalah menyejahterakan warga negaranya. Hal ini bisa kita lihat dari sejarah terbentuknya UndangUndang Dasar Negara Republik Indonesia Tahun 1945 (UUD 1945) hingga pasca amandemen

\footnotetext{
38 Ibid.

39 Pieter Mahmud Marzuki. 2007. Penelitian Hukum. Edisi Pertama Cetakan Ketiga. Kencana, Jakarta Hal 171.

40 Jimly Asshiddiqie. 1997. Teori \& Aliran Penafsiran Hukum Tata Negara. Jakarta: Ind. Hill.Co. Hal. 17-18.
}

pada tahun 2004, dimana secara normatif memperlihatkan bahwa negara hukum Indonesia menggunakan paham negara kesejahteraan. ${ }^{41}$ Maknanya adalah pemerintah memiliki kewajiban untuk menjamin tercapainya kehidupan yang baik atau layak bagi setiap warga negaranya. Oleh karenanya, UUD 1945 mengatur mengenai politik hukum sistem perekonomian nasional, dimana negara mendapat peran strategis dalam kegiatan ekonomi. Peran strategis ini antara lain adalah sebagai penjamin (provider) kesejahteraan negara, pengatur (regulator), pengusaha (entrepreneur), dan wasit (umpire) yang menentukan standarstandar yang adil baik bagi perusahaan swasta maupun perusahaan negara. ${ }^{42}$ Peran strategis ini juga memberikan kewenangan negara untuk menguasai bidang-bidang produksi penting yang terkait dengan hajat hidup orang banyak.

Berkaitan dengan fungsi strategis negara dalam bidang ekonomi tersebut, maka keberadaan Badan Usaha Milik Negara (BUMN) dan Badan Usaha Milik Daerah (BUMD) adalah instrument negara yang memiliki visi untuk meningkatkan kesejahteraan masyarakat melalui mekanisme korporasi. Mekanisme korporasi ini indentik dengan profit oriented, sementara perusahaan negara maupun daerah salah satu misinya menyelenggarakan pelayanan umum (public service). Dengan demikian, ketika negara berperan sebagai salah satu pemain dalam bidang bisnis atau perekonomian, maka keempat fungsi penting sebagaimana telah disebutkan di atas harus bisa dijalankan dengan proporsional dan tidak saling berbenturan.

Keterlibatan negara dalam bidang ekonomi, menurut Friedman diletakkan pada tiga bentuk perusahaan negara, yaitu: (1) department government enterprise, adalah perusahaan negara yang merupakan bagian integral dari suatu departemen pemerintahan yang kegiatannya bergerak di bidang public utilities; (2) statutory public corporation, adalah perusahaan negara yang sebenarnya hampir sama dengan departement government enterprise, hanya dalam hal manajemen lebih otonom dan bidang usahanya masih tetap public utilities; (3) commercial companies, adalah perusahaan yang merupakan campuran modal swasta dan diberlakukan hukum

\footnotetext{
41 Suteki. Rekonstruksi Politik Hukum, Hak Atas Air, Pro Rakyat. (Semarang: Surya Pena Gemilang, 2010), hlm 52. 42 Ibid.
} 
privat. ${ }^{43}$ Konsep Friedman ini sebetulnya diadopsi oleh pemerintah Indonesia, dalam pengelolaan BUMD. Dalam PP BUMD disebutkan bahwa bentuk hukum BUMD adalah Perusahaan Umum Daerah yang fokus pada sektor public utilities dan BUMD dengan bentuk hukum Perusahaan Persero Daerah yang fokusnya adalah mengejar keuntungan (commersial companies). Jadi, sebenarnya telah ada sebuah road map sederhana mengenai pengelolaan BUMD terkait posisi pemerintah daerah sebagai pelaku usaha. Namun, pengelolaan kebutuhan strategis yang terkait hajat hidup orang banyak memerlukan investasi yang besar, yang tidak bisa ditanggung sendiri oleh kemampuan pemerintah daerah.

Dalam perkembangannya, era globalisai ekonomi dan otonomi daerah berdampak pada perlunya upaya pemberdayaan melalui peluang besar investasi, sehingga ada bidang strategis yang tak luput dari kebijakan ini, misalnya, bidang air. Jika mencermati kebijakan privatisasi air yang dilakukan oleh Pemerintah Provinsi (Pemprov) DKI Jakarta, dimana dalam perjalanannya pemerintah daerah kehilangan posisi dominan dalam pengelolaan air dan akibatnya masyarakat DKI kesulitan memenuhi kebutuhan pokok air karena mahal, maka hal ini membuktikan bahwa kebijakan yang diambil oleh Pemprov DKI Jakarta itu lebih cenderung (condong) kepada unsur profit perudahaan daerahnya. Hal ini sekaligus membuktikan bahwa tidaklah mudah mencari solusi atas benturan nilai bisnis dengan nilai pelayanan umum ketika sektor produksi sudah melibatkan pihak swasta.

Kembali kepada peran negara dalam tugas kesejahteraannya, maka dapat dikemukakan konsep ekonomi kesejahteraan dan kemiskinan dari Amartya Kumar Zen bahwa kemiskianan dapat diatasi apabila hak-hak dasar masyarakat dapat dipenuhi. ${ }^{44}$ Konsep Amartya Zen ini menitik beratkan pada kebijakan-kebijakan pemerintah yang harus berpihak kepada masyarakat, dengan kalimat lain ia hendak mengemukakan bahwa negara adalah satu-satunya kunci agen perubahan sosial yang harus diandalkan. Sebagaimana konsep Roscou Pound (pionir dari aliran sociological jurisprudences) yang mengemukakan bahwa

43 Ibrahim, R. (2007). Landasan Filosofis dan Yuridis Keberadaan BUMN: Sebuah Tinjauan. Jurnal Hukum Bisnis. 26 (1), 5-14.

44 Syawaluddin S, 2015. Refleksi Atas Pemikiran Amartya Kumar Zen Tentang Ketimpangan Dan Kemiskinan, AlBuhuts, Volume 11 Nomor 1, Juni 2015, Hal 1-10. hukum harus dilihat sebagai suatu hubungan kemasyarakatan yang berfungsi untuk memenuhi kebutuhan-kebutuhan sosial. Selanjutnya Roscou Pound berpendapat bahwa hukum itu merupakan a tool of social engineering yang terjemahannya hukum sebagai pranata sosial atau hukum sebagai alat untuk membangun masyarakat. Fungsi hukum sebagai alat pengendalian sosial maka hukum itu bertugas untuk menjaga agar masyarakat tetap dapat berada di dalam pola-pola tingkah laku yang semestinya.$^{45}$ Di dalam peranannya yang demikian ini, hukum hanya mempertahankan apa saja yang telah menjadi sesuatu yang tetap dan diterima dalam masyarakat atau hukum sebagai penjaga status quo, tetapi di luar itu hukum masih dapat menjalankan fungsinya yang lain, yaitu dengan tujuan utuk mengadakan perubahan-perubahan di dalam masyarakat. Dalam bidang ekonomi, peran hukum diharapkan mampu menampung dinamika kegiatan ekonomi dengan menciptakan kegiatan yang efesien dan produktif, serta mengandung daya prekditabilitas. ${ }^{46}$ Maknanya, pemerintah diuji kemampuan dan kemauannya untuk mensinergikan (harmonisasi) kepentingan negara melalui tujuan nasional yang termaktub dalam pembukaan UUD 1945 dengan tekanan ekonomi dan politik globalisasi. Hal ini bisa dipahami, mengingat sampai sekarang mewarisi perekonomian kolonial kapital melalui praktik kapitalistik dan konglomerasi ekonomi. ${ }^{47}$

Sebuah kajian mengemukakan bahwa era reformasi hukum di Indonesia belum berpihak kepada kepentingan masyarakat. Hukum masih sarat dengan kepentingan-kepentingan pihak tertentu seperti penguasa dan pegusaha. Hal ini terlihat dari produk undang-undang untuk skala nasional dan peraturan daerah untuk skala lokal. Reformasi terhadap aparatur penegak hukum berjalan lambat jika dibandingkan dengan reformasi terhadap substansi hukum. Hal ini menyebabkan hukum tidak dapat berperan sebagai penyeimbang kepentingan masyarakat dalam upaya merealisasikan keadilan dan kebenaran. ${ }^{48}$

45 Mocthar Kusumaatmadja, Konsep-Konsep Hukum Dalam Pembangunan, 2013. Pusat Studi Wawasan Nusantara, Bandung, PT.Alumni, Hal 19-24.

46 Adi Sulistiyono dan Muhammad Rustamji, 2009. Hukum Ekonomi Sebagai Panglima. Sidoarjo: Masmedia Buana Pustaka. Hal 18.

47 Ibid, Hal 157.

48 Eman Sulaiman , 2013. Hukum Dan Kepentingan Masyarakat (Memosisikan Hukum sebagai Penyeimbang Kepentingan Masyarakat), Jurnal Hukum Diktum, Volume 11, 
Berkaitan dengan kegiatan bisnis yang dijalankan oleh BUMD, maka harus ada penegasan mengenai politik hukum regulasi BUMD bahwa tugas pemerintah daerah adalah perpanjangan tangan dari Pemerintah Pusat (negara) yang harus mengawal terwujudnya kesejahteraan masyarakat. Dengan demikan, ketika pemerintah daerah dituntut berperan sebagai pelaku usaha, maka bukan berarti ia harus kehilangan jati dirinya sebagai agen perubahan sosial. Dengan kalimat lain, bisnis yang dijalankan oleh pemerintah daerah bukan merupakan kegiatan bisnis yang murni, melainkan kegiatan bisnis dalam kontek tugas pemerintahannya di daerah.

\section{Perlunya Sinergi Antara Unsur Bisnis Dan Unsur Pemerintahan Dalam Fungsi Pemerintah Daerah Sebagai Pelaku Usaha.}

Antinomi yang berasal dari bahasa latin antinomia yang artinya anti-nomos atau anti norma, sehingga secara harfiah merupakan pertentangan norma. Sebuah pertentangan antara dua hal yang terlihat setara (equelly) dalam sebuah aturan hukum positif. Konsep antinomi ini berasal dari perdebatan dalam ranah filsafat hukum, yang berawal dari pemikiran David Hume bahwa selalu ada pertentangan (konflik) dalam sebuah prinsip. ${ }^{49}$ Gustav Radbruch dengan konsep idee des rech mengungkapkan bahwa cita-cita hukum diletakan pada tiga prinsip utama, yakni kepastian, keadilan, dan kemanfaatan. Dalam proses penegakan hukum, ketiga prinsip hukum ini harus diaplikasikan secara seimbang atau proposional, tetapi kenyataannya tidaklah mudah mengingat prinsip-prinsip ini hakikatnya saling bertentangan. ${ }^{50}$

Immanuel Kantberpendapat mengenai konsep antinomi berdasarkan pertentangan fundamental antara alam dan akal manusia, dimana alam akan mengikuti kebutuhannya sementara akal manusia memiliki tujuan sediri dan kehendak yang bebas. ${ }^{51}$ Lebih lanjut Friedman mengemukakan bahwa pertentangan-pertentangan ini terjadi diakibatkan oleh sifat alamiah hukum itu sendiri yang berada di antara nalar filsafat dan kepentingan pragmatis. Cita-cita keadilan hukum dikonstruksikan melalui

Nomor 1, Januari 2013, hlm 100 - 110.

49 Zainal Arifin Mochtar, 2015. Antinomi Dalam Peraturan Perundang-Unangan Di Indonesia, Antinomy In Legislation In Indonesia, Halrev, Faculty Of Law Of Hasanudin University, Volume 1 Issue 3, Desember 2015, Hal 319.

$50 \quad$ Ibid, Hal 321.

51 Ibid, Hal 320 mekanisme yang cenderung bersifat pragmatis, sehingga hukum bukan merupakan konsep alamiah melainkan terbentuk melalui internalisasi, interusi, dan proses negoisasi berbagai kepentingan aktoraktornya. $^{52}$

Di awal telah disampaikan bahwa dalam pengelolaan BUMD terdapat benturan nilai dan kepentingan, yakni benturan antara nilai dan kepentingan bisnis yang ruhnya adalah mengejar keuntungan, dengan nilai sosial berupa pelayanan umum yang harus dilakukan oleh pemerintah daerah yang berperan selaku pelaku usaha. Dua hal ini jelas berbeda secara mendasar, sebab dalam bisnis ada perhitungan untung dan rugi, sedangkan dalam misi pelayanan pemerintah daerah tidak memperhitungan untung rugi sebab merupakan mandat konstitusi. Jika mengkaji tujuan dibentuknya BUMD, yang antara lain untuk memberi manfaat kepada perkembangan perekonomian daerah, meyenggarakan kemanfaatan umum atas tersedianya barang dan jasa yang bermutu, dan memperoleh laba (keuntungan), ${ }^{53}$ maka terdapat antinomi antara prinsip kemanfaatan dengan keadilan. Menurut penulis, tarik-menarik antara unsur bisnis dan unsur pelayanan umum, secara teoritik merupakan pertentangan antara paham individualisme dan kolektivitas yang terkait juga dengan paham internasionalisme serta nasionalisme.

Paham individualisme tidak memandang sekat-sekat negara sebagai penghalang bagi terwujudnya persamaan sehingga ia juga menjadi pendorong bagi berkembangnya internasionalisme. Sebaliknya, paham kolektivitas cenderung kepada nasionalisme sebab kaum nasionalis memandang negara adalah lembaga (wadah) yang paling baik bagi kepentingan masyarakat dan individu. ${ }^{54}$ Dalam kontek BUMD sebagai sebuah perusahaan, ketika Kepala Daerah mewakili Pemerintah Daerah dalam kepemilikan kekayaan daerah yang dipisahkan, ${ }^{55}$ maka hakikatnya merepresentasikan kepemilikan kolektif (publik) atas perusahaan tersebut, sebab Negara Kesatuan Republik Indonesia menganut sistem kedaulatan rakyat ${ }^{56}$ artinya pemegang kekuasaan tertinggi 52 Loc.Cit.

53 Republik Indonesia, Peraturan Pemerintah Nomor 54 tahun 2017 Tentang BUMD, Op.Cit., Pasal 7.

54 Ibid, Hal 324

55 Republik Indonesia, Peraturan Pemerintah Nomor 54 tahun 2017 Tentang BUMD, Op.Cit., Pasal 3.

56 Republik Indonesia, Undang-Undang Negara Indonesia Tahun 1945, Op.Cit., Pasal 1 Ayat (2). 
adalah rakyat. Sedangkan, konsep bisnis yang identik dengan sektor privat cenderung kepada kepemilikan individu. Oleh karena itu, apabila unsur bisnis yang mendominasi dalam kegiatan BUMD maka nilai kemanfaatan yang dirasakan publik tidak memenuhi rasa keadilan, terlebih jika bidang usaha yang dilakukan BUMD itu terkait dengan hajat hidup orang banyak. Contoh kongkritnya adalah kebijakan privatisasi air yang dilakukan oleh Pemerintah Provinsi DKI Jakarta.

Hukum adalah suatu sistem atau tatanan yang maknanya merupakan sebuah kesatuan, ia bersifat lengkap, ${ }^{57}$ terdiri dari unsur-unsur yang saling berinteraksi satu sama lain, ${ }^{58}$ maka sangat berpeluang terjadi konflik. Namun, dalam sebuah kesatuan tidak dikehendaki adanya konflik, pertentangan, atau kontradiksi antara bagianbagian itu, sehingga konflik akan diselesaikan oleh sistem itu sendiri ${ }^{59}$ melalui penafsiranpenafsiran. ${ }^{60}$ Sistem hukum bersifat kontinu, berkesinambungan, dan otonom, sehingga berfungsi menjaga keseimbangan tatanan dalam masyarakat (resitutio in integrum). ${ }^{61}$ Oleh karena itu, antinomi dalam norma hukum dapat diselesaikan dengan mengkaji pilar-pilar antinomi itu sendiri. Pilar-pilar antinomi dalam kegiatan BUMD yang terkait bidang strategis dan hajat hidup orang banyak adalah pilar keadilan, kemanfaatan, kolektivitas, serta individualistis. Dalam teori penegakan hukum, apabila pertentangan terjadi antara unsur keadilan dan kemanfaatan, maka lebih didahulukan unsur kemanfaatannya. ${ }^{62}$ Dengan demikian, ketika Pemerintah Daerah melakukan kegiatan bisnis, dimana kepemilikan atas bisnis itu adalah hakikatnya secara kolektif (dimiliki oleh masyakarat), maka kemanfaatannya harus lebih banyak dirasakan oleh masyarakat. Artinya, dalam bidang usaha strategis yang terkait hajat hidup orang banyak, paradigma keuntungan yang diperoleh adalah terselenggaranya pelayanan umum yang optimal.Dengan kalimat lain, BUMD dianggap untung apabila telah mampu menyelenggarakan kemanfaatan umum dimana produktivitas dari BUMD tersebut mampu

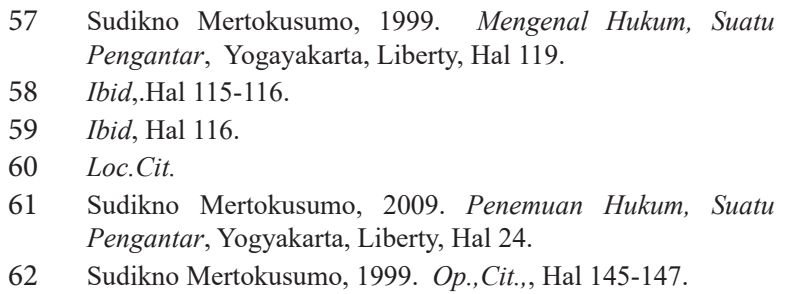

memberikan kenikmatan bagi orang banyak.

\section{Kesimpulan}

Dari pemaparan pembahasan di atas, maka dapat disimpulkan bahwa konsep bisnis harus ada dalam fungsi pemerintahan daerah sebagai implementasi kegiatan pemerintahan dalam kerangka otonomi daerah, sehingga makna bisnis yang dijalankan oleh pemerintah daerah esensinya adalah mempercepat terwujudnya kesejahteraan masyarakat. Sedangkan, antinomi dalam pengelolaan BUMD, yakni benturan antara unsur negara yang identik dengan pelayananumum dengan unsur bisnis yang karakteristiknya mengejar keuntungan harus disikapi dengan perubahan paradigma pemerintah daerah dalam memaknai keuntungan BUMD. Paradigma baru mengenai keuntungan ini tidak melihat keuntungan dalam kontek material yang masuk ke dalam kas daerah, namum keberhasilan penyelenggaraan kepentingan umum (pelayanan umum) sebagai parameter baru dalam konsep keuntungan (provit) bagi pemerintah daerah. Oleh karena itu, disarankan untuk memberikan rumusan yang jelas mengenai tugas pelayanan umum dalam bidangbidang produksi yang terkait hajat hidup orang banyak dalam regulasi yang mengatur mengenai BUMD.

\section{REFERENSI}

Buku

Adi Sulistiyono dan Muhammad Rustamji, Hukum Ekonomi Sebagai Panglima. Sidoarjo: Masmedia Buana Pustaka, 2009.

Burhan ashshofa, Metode Penelitian Hukum. Jakarta: Rineka Cipta, 2007.

Jimly Asshiddiqie. Teori \& Aliran Penafsiran Hukum Tata Negara. Jakarta: Ind. Hill. Co,1997.

Jimmly Asshiddiqie, Hukum Tata Negara dan Pilar-Pilar Demokrasi. Jakarta: Konstitusi Press, 2005.

Johny ibrahim, Teori, Metode Dan Penelitian Hukum Normatif. Malang-Jawa Timur: Bayumedia Publishing, 2007. 
Pieter Mahmud Marzuki. Penelitian Hukum, Edisi Pertama Cetakan Ketiga, Jakarta: Kencana, 2007.

Peter Mahmud Marzuki, Penelitian Hukum, Edisi Revisi, Jakarta: Kencana, 2017.

Soerjono Soekanto, Pengantar Penelitian Hukum. Jakarta: UI Press, 2007.

Sudikno Mertokusumo, Mengenal Hukum, Suatu Pengantar, Yogayakarta: Liberty. 1999.

Sudikno Mertokusumo, Teori Hukum. Bahan Kuliah Magister Ilmu Hukum UGM, 2002.

Sudikno Mertokusumo, Penemuan Hukum: Suatu Pengantar, Yogyakarta: Liberty, 2009.

Mocthar Kusumaatmadja, Konsep-Konsep Hukum Dalam Pembangunan. Bandung: Pusat Studi Wawasan Nusantara, PT.Alumni. 2013.

Suteki, Rekonstruksi Politik Hukum: Hak Atas Air, Pro Rakyat. Semarang: Surya Pena Gemilang, 2010.

Zaeni Asyhadie, Hukum Bisnis, Prinsip Dan Pelaksanaanya Di Indonesia. Jakarta: Rajawali Press, 2005.

\section{Jurnal dan Penelitian Ilmiah}

Eman Sulaiman, Hukum Dan Kepentingan Masyarakat (Memosisikan Hukum sebagai Penyeimbang Kepentingan Masyarakat), Jurnal Hukum Diktum, Volume 11, Nomor 1, Januari 2013. 100-110.

Fence M. Wantu, Antinomi Dalam Penegakan Hukum Oleh Hakim, Mimbar Hukum, Volume 19, Nomor 3, Oktober 2007, 335485.

Ibrahim, R. Landasan Filosofis dan Yuridis Keberadaan BUMN: Sebuah Tinjauan. Jurnal Hukum Bisnis. 26 (1), 2007, 5-14.

Jiwa Sarana, Pusat Penelitian Ekonomi, Lembaga Ilmu Pengetahuan Indonesia (P2E-LIPI), Revitalisasi BUMD Dalam Perekonomian Daerah. LIPI Press. 2010.

Khasazah, Friedrich Karl Von Savigny. Padjadjaran Jurnal Ilmu Hukum, Volume 2, Nomor 1 Tahun 2015 (ISSN 2460-1543), (E-ISSN 2442-9325), 197-208.
Syawaluddin S, Refleksi Atas Pemikiran Amartya Kumar Zen Tentang Ketimpangan Dan Kemiskinan, Al-Buhuts, Volume 11 Nomor 1, Juni 2015. 1-10.

Wihana Kirana Jaya. Policy Brief Badan Usaha Milik Daerah (BUMD). Dalam Studi Potensi Pendapatan Asli Daerah Provinsi Daerah Istimewa Yogyakarta, Pusat Studi Ekonomi dan Kebijakan Publik (PSE-KP) UGM. 2007.

Zainal Arifin Mochtar, Antinomi Dalam Peraturan Perundang-Unangan Di Indonesia, Antinomy In Legislation In Indonesia, Halrev, Faculty Of Law Of Hasanudin University, Volume 1 Issue 3, Desember 2015, 316-336.

\section{Sumber On Line}

https://sistempemerintahannegaraindonesia. blogspot.com/2016/04/isi-kedudukan-danmakna-pembukaan-uud.html.

\section{Perundang-Undangan}

Undang-Undang Dasar Negara Republik Indonesia Tahun 1945 pasca perubahan pertama, kedua, ketiga dan keempat yang ditetapkan pada tanggal 10 Agustus 2002.

Undang-undang Nomor 5 Tahun 1962 tentang Perusahaan Daerah, Lembaran Negara Republik Indonesia, dan Tambahan Lembaran Negara Tahun 1962.

Undang-Undang Nomor 23 Tahun 2014 tentang Pemerintahan Daerah, Lembaran Negara Republik Indonesia Tahun 2014 Nomor 244, Tambahan Lembaran Negara Republik Indonesia Nomor 5587.

Peraturan Pemerintah Nomor 54 Tahun 2017 Tentang Badan Usaha Milik Daerah, Lembaran Negara Republik Indonesia Tahun 2017 Nomor 344, dan Tambahan Lembaran Negara Republik Indonesia Nomor 5801.

Putusan Mahkamah Agung Nomor 31/K/PDT/2017 Tentang Putusan gugatan terhadap kebijakan privatisasi air Pemerintah Provinsi DKI Jakarta. 